$\operatorname{cocos}(2004), 16,37-42$

Printed in Sri Lanka

\title{
EFFECT OF DIFFERENT CONTROL METHODS OF IMPERATA CYLINDRICA ON COCONUT (COCOS NUCIFERA) YIELD IN LOW COUNTRY DRY ZONE OF SRI LANKA
}

\author{
A D Samarajeewa, R P B S H S Senaratna and K C P Perera \\ Coconut Research Institute, Lunuwila, Sri Lanka
}

\begin{abstract}
Five methods of control of Imperata cylindrica (L.) Beauv namely a) harrowing with disc harrow, b) Glyphosate ( $N$ - Phosphonomethyl Glycine) $2.88 \mathrm{~kg}$ a.i / ha, c) Glyphosate $1.44 \mathrm{~kg}$ a.i/ha, d) circle weeding with Glyphosate (1.44 kg a.i/ha) along with mechanical slashing rest of the area, and e) mechanical slashing were evaluated to determine the cost effective method of control of Imperata cylindrica, and to ascertain the effect of coconut -Imperata competition on yield of coconut in Low Country Dry zone in Sri Lanka. An unweeded plot was used as the control. Experiment was arranged in a Randomized Complete Block design with three replicates. Treatments were applied twice a year in six months interval. Glyphosate at the rate of 2.88 and Glyphosate $1.44 \mathrm{~kg}$ a.i/ha gave a significant reduction $(P<0.05)$ of weed biomass when compared to other treatments. A significant increase $(P<0.05)$ of coconut yield was observed due to control of imperata in plots with these treatments at two years after imposition of treatments .When cumulative average yield of coconut was considered for three consecutive years, control of Imperata with Glyphosate gave a $54 \%$ increase $(P<0.01)$ of nut yield when compared to the unweeded control. Cost - benefit analysis of different control methods revealed that the application of Glyphosate at the rate of $1.44 \mathrm{~kg}$ a.i/ha was the most cost effective (undiscounted B/C ratio: 5.9) method of control of Imperata in sandy soils in the Low Country Dry Zone of the Coconut Triangle.
\end{abstract}

\section{INTRODUCTION}

Coconut is by far the most extensively cultivated plantation crop in Sri Lanka. The growth habit of the palm and its' canopy structure requires a wide spacing, which permits abundant sunlight available to the understory. As a result the unutilized space under coconut could get invaded with weeds, which compete for soil moisture and nutrients reducing the growth and yield of coconut palm and obstruct routine agronomic practices (Liyanage and Liyanage, 1992). Of the perennial grass weeds, Imperata cylindrica is the most noxious and troublesome weed not only in coconut plantations but also in other crop ecosystems as well (Renaldo et al., 1980). 
This species tolerate shade up to $50 \%$ and thrives well under mature coconut plantations (Soerjani, 1970).

Imperata is found abundantly in coconut plantations in Intermediate Dry zone of Sri Lanka, particularly in marginal coconut lands with sandy soils. The ability of Imperata to thrive well in marginal coconut lands particularly in sandy soils, aggravates the problem of weed competition in coconut. This emphasizes the importance of eradication of Imperata from coconut lands as it is an aggressive, rhizomatus perennial grass, which reproduces profusely from both seeds and rhizomes (Mercado, 1986). Of the various methods used to control Imperata, impact of repeated slashing and tillage, replacement of Imperata with leguminous cover crops and chemical methods have been reported by several authors (Mercado, 1986; Liyanage and Liyanage, 1992; Renaldo et al., 1980). Although leguminous cover cropping has been reported to be the most effective method of controlling Imperata (Renaldo et al., 1980), it is difficult to establish leguminous covers in coconut lands with sandy soils. This study envisages to find the effectiveness of use of several mechanical and chemical means of control Imperata and to assess the impact of coconut - Imperata competition on the yield of coconut.

\section{MATERIALS AND METHODS}

The experiment was conducted at Mangalaeliya in Puttlam District in low country dry zone of Sri Lanka from 1997 to 2000. Soil at the location was sandy and belongs to the great soil group of Sandy Regosols. The mean annual rainfall and temperatures were $1492 \mathrm{~mm}$ and $23.8-31.5^{\circ} \mathrm{C}$, respectively. Following treatments were imposed.

T1 - Harrowing with disc harrow

T2 - Application of Glyphosate $2.88 \mathrm{~kg}$, a.i. / ha

T3 - Application of Glyphosate $1.44 \mathrm{~kg}$, a.i. / ha

T4 - Circle weeding with application of Glyphosate ( $1.44 \mathrm{~kg}$, a.i. / ha) and slashing the rest of the area

T5 - Mechanical slashing of Imperata

T6 - Unweeded (control)

The experiment was laid in a randomized complete block design with three replicates. Each plot comprised of six effective palms of around thirty years. Slashing was done with a tractor-mounted rotary slasher while harrowing was done to a depth of $15 \mathrm{~cm}$ using tractor mounted disc- harrow. Spraying of weedicide was done with a knapsack sprayer. Treatments were imposed twice a year in six monthly intervals. Weed biomass was ascertained by quadrate sampling $\left(0.5 \mathrm{~m}^{2}\right.$ quadrate) followed by oven drying at $105^{\circ} \mathrm{C}$ for 
24 hrs. Harvesting of coconut palms in each plot was done at two monthly intervals. Total yield for a year was obtained from all six palms.

$\mathrm{B} / \mathrm{C}$ ratio was used to determine the cost effectiveness of different /mperata control methods. Benefits were calculated as the average incremental yield per year over the Imperata uncontrolled, considering the yields of previous three years.

\section{RESULTS AND DISCUSSION}

Effect of different control methods on reduction of shoot biomass of Imperata

Figure 01 illustrates the reduction of biomass of Imperata due to different control methods over time. Of the various methods used, slashing in six months interval had the least effect on biomass of Imperata. According to Sandnam et al., (1977), slashing at shorter intervals, results in better control of this weed. However slashing Imperata at shorter intervals in coconut lands may not be cost effective. Disc harrowing in six month- interval has reduced the biomass of Imperata better than slashing. This is probably due to the fragmentation of under ground parts thus, desiccation of the rhizomes. Effectiveness of control of Imperata by successive soil cultivation has been reported by several authors (Knows and Cole, 1973; Ivens, 1975, Mercado, 1986). Martin, (1975), has recommended successive tillage with disc harrowing at 8-10 week intervals for better control of Imperata.

Control of Imperata with Glyphosate( N- Phosphonomethyl glycine) at the rate of 2.88 and $1.4 \mathrm{~kg}$ a.i /ha (Counter-a.i., $356 \mathrm{~g} / \mathrm{l}$ ) gave a significant reduction $(P<0.05)$ of weed biomass when compared to other methods. Effectiveness of glypohsate for control of Imperata has been reported by several authors (Rognon et al., 1984; Wrong 1971; Golan 1976; Mercado, 1986; Liyanage et al., 1992). Although an integrated approach i.e. application of glyphosate followed by establishment of leguminous creeping covers was found to be effective in controlling Imperata (Liyanage et al., 1992; Renaldo et al., 1980), practical difficulties of establishment of cover crops in sandy soils in Low Country Dry Zone in the coconut triangle pave the way for the present study to opt for alternative methods of control. 


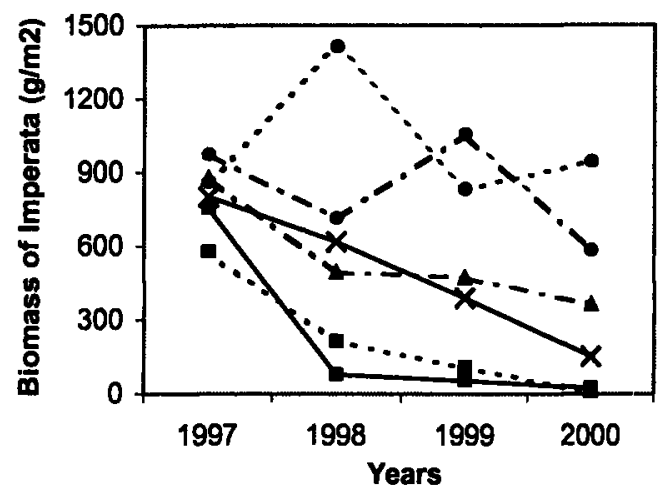

- - L - - Harrowing (Twice/year) - Gyphosate( 8 ina) $\ldots-$. . - Gyphosate( 4 lha)

Figure1: Effect of weed control methods on biomass yield of Imperata

\section{Effect of Imperata on yield of Coconut}

Control of Imperata resulted in a significant increase $(P<0.05)$ in nut yield over the uncontrolled plots even a year after imposition of treatments. Impact of Imperata on nut yield was clearly shown after 2 years of treatment application, where increase in nut yield was $102 \%$ and $49 \%$ respectively with glyphosate treatments (average of two concentrations) when compared to unweeded control in the years 1999 and 2000 . When the cumulative yield of 3 years were considered, control of Imperata with glyphosate has increased the nut yield by $55 \%$, when compared to the unweeded control. Imperata cylindrica is a strong competitor for soil nutrients and moisture resulting in poor growth and reduction of nut yield (Renaldo et al., 1980). Martin and Mudlier (1983) reported a reduction of copra yield by $14 \%$ due to coconut- weed competition in general. However literature on degree of competition exerted by Imperata on yield of coconut is scarce.

Of the rest of the treatments, control of Imperata with harrowing or slashing did not contribute for a significant increase in nut yield on yearly basis (Table1). Eighty percent of the root zone of coconut is confined in the circular area with in the radius of $2 \mathrm{~m}$ from the coconut boll (Liyanage, 1985), which is referred to as "manure circle". It is expected to keep the manure circle free from weeds to reduce the coconut-weed competition. However the present study showed that weeding in the manure circle with glyphosate has not significantly reduced the coconut- weed competition (Fig. 2) in the case of Imperata infestation. 
Table 1: Effect of different control methods of Imperata on yield of coconut

\begin{tabular}{|c|c|c|c|c|c|}
\hline \multirow[t]{2}{*}{ Treatments } & \multicolumn{4}{|c|}{ Year } & \multirow[b]{2}{*}{$\begin{array}{l}\text { Cumulative average } \\
\text { yield per palm }{ }^{1}\end{array}$} \\
\hline & 1997 & 1998 & 1999 & 2000 & \\
\hline Harrowing & 31 & 43 & 56 & 56 & $52(18)$ \\
\hline $\begin{array}{l}\text { Glyphosate } 2.88 \\
\text { kgs, a.i. / ha }\end{array}$ & 27 & 45 & 88 & 72 & $69(56)$ \\
\hline $\begin{array}{l}\text { Glyphosate } 1.44 \\
\text { kgs, a.i. / ha }\end{array}$ & 32 & 54 & 82 & 65 & $67(52)$ \\
\hline $\begin{array}{l}\text { Circle weeding } \\
\text { with Glyphosate }\end{array}$ & 33 & 35 & 56 & 57 & $51(16)$ \\
\hline Slahing & 33 & 45 & 60 & 55 & $53(20)$ \\
\hline $\begin{array}{l}\text { Unweeded } \\
\text { control }\end{array}$ & 35 & 45 & 42 & 46 & 44 \\
\hline Significance & NS & * & ** & * & $\star \star \star$ \\
\hline CV \% & & 10 & 16 & 13 & 7 \\
\hline LSD & & 9 & 19 & 14 & 8 \\
\hline
\end{tabular}

NB. Values were rounded to the nearest digit.

${ }^{1}$ Cumulative annual average yield for year 1998,1999 and 2000

* = Significance at $5 \%,{ }^{* *}=$ Significance at $1 \%$, NS $=$ Not significant

Values in parentheses are the percentage increase of nut yield over the control

\section{Cost/Benefit analysis of control methods of Imperata}

Table 2: Costs and benefits of different control methods of Imperata

\begin{tabular}{|c|c|c|c|c|}
\hline $\begin{array}{l}\text { Method of } \\
\text { control }\end{array}$ & $\begin{array}{l}\text { Costs* } \\
\text { (Rs/hal } \\
\text { annum) }\end{array}$ & $\begin{array}{l}\text { Average } \\
\text { annual } \\
\text { incremental } \\
\text { yield/ha }\end{array}$ & $\begin{array}{l}\text { Incremental } \\
\text { benefits (Rs.) } \\
\text { @ Rs.9.00/nut }\end{array}$ & $\begin{array}{l}\text { Undiscounted } \\
\mathrm{B} / \mathrm{C} \text { ratio }\end{array}$ \\
\hline $\begin{array}{l}\text { Harrowing } \\
\text { Application of }\end{array}$ & 6000.00 & 1280 & 11520.00 & 1.92 \\
\hline $\begin{array}{l}\text { Glyphosate } 2.88 \\
\text { kgs, a.i. / ha }\end{array}$ & 9600.00 & 4000 & 36000.00 & 3.75 \\
\hline $\begin{array}{l}\text { Application of } \\
\text { Glyphosate } 1.44 \\
\text { kgs, a.i. / ha }\end{array}$ & 5600.00 & 3680 & 33120.00 & 5.91 \\
\hline $\begin{array}{l}\text { Circle weeding } \\
\text { with Glyphosate } \\
\text { and slashing }\end{array}$ & 9500.00 & 1120 & 10080.00 & 1.06 \\
\hline Slahing & 7500.00 & 1440 & 12960.00 & 1.73 \\
\hline
\end{tabular}

Values are in Sri Lankan Rupees (I US $\$=$ SLR. 102.00)

- Include material machinery and labour costs for twice a year

Average price of commercial product of Glyphosate : Rs. $400 /$ liter ( $360 \mathrm{~g}$ a.i./litre)

Average labour wage: Rs.200/manday 
The costs of different methods of control of Imperata are given in the Table 2. Although the highest increase of nut yield was achieved in plots treated with glyphosate at $2.88 \mathrm{~kg}$ of a.i. /ha, the highest returns to investment (B/C ratio: 5.9 ) was given by the plots treated with glyphosate at $1.44 \mathrm{~kg}$ a.i./ha, thus making it the most effective method of control of Imperata among the tested treatments.

\section{CONCLUSION}

Imperata cylindrica is a strong competitor for coconut reducing, the nut yield. This study showed that control of Imperata with glyphosate in coconut lands with sandy soil in low country dry zone increased the nut yield by $55 \%$ when compared to that of unweeded plots. Application of glyphosate at the rate of $1.44 \mathrm{~kg}$ a.i (4 litres of commercial mixture; Counter-a.i., $356 \mathrm{~g} / \mathrm{l}$ ) found to be cost effective method of controlling Imperata in coconut lands in low country dry Zone.

\section{REFERENCES}

Renaldo G. and San Juan C. (1980). Replacement of "Cogan" (Imperata cylindrica. (I.) Beau. vegetation under coconut with leguminous cover crops, The Philippine Journal of COCONUT STUDIES, pp 32- 39

Liyanage, L.V.K. and Liyanage, M.de.S (1992). Weed control- Understory weed management in coconut lands, CORD (1) viii. pp 48-56.

Soerjani,M. (1970). Alang-alang, Imperata cylindrica (L.) Beauv. Pattern of growth as related to its problem of control, BIOTROP Bull.(1) pp88.

Beatriz L. Mercado (1986). Control of Imreata cylindrica. In. Weed control in Tropical Crops ( Ed. K.Moody), Vol.II, Philippines Weed Science Society, pp 269-278.

Sandanum, S. and Jayasinghe, H.D. (1977). Manual and Mechanical control of Imperata cylindrica on tea lands in Sri Lanka, PANS 23, pp 421-426.

Martin, G. (1975). Land preparation of Imperata savannale or grass pasture, Oleagineux 30, pp 467-470.

Martin, M.P.L.D and Mudaliar, T. (1983). Response of coconut to fertilizer application and weed control, Fiji Agric.J.45 (2), pp 51-53. 